\title{
An economic assessment of risk and returns from prescribed burning on tallgrass prairie
}

\section{D.J. BERNARDO, D.M. ENGLE, AND E.T. MCCOLLUM}

\begin{abstract}
A stochastic (Monte Carlo) simulation model was developed to evaluate the influence of prescribed burning on the expected value and variability of net returns from a representative stocker cattle enterprise. The model was applied to both shallow prairie and eroded prairie range sites in eastern Oklahoma. Prescribed burning is shown to be an economically feasible means of improving the productivity of eastern redcedar infested rangeland. Implementation of an annual burning program resulted in a $\$ 69.00$ and $\$ 4.80$ per hectare increase in the net present value of the 10-year return stream generated from stocker cattle production on shallow prairie and eroded prairie range sites, respectively. Prescribed burning does not increase the variability of annual income from stocker cattle production. However, when riak is measured in terms of relative variability (coefficient of variation) or the probability of annual returus below zero, prescribed burning is determined to be a risk-reducing practice.
\end{abstract}

Key Words: plant control, eastern redcedar Juniperus virginiuna, range improvements, stochastic simulation model, profitability, risk, variability of returns

Maintenance and improvement of the productivity of Oklahoma's rangeland is critical to the long-run profitability of the state's beef cattle industry. Considerable concern has been expressed by decision makers and agriculturalists as to the declining condition and productivity of Oklahoma's range resource. Recent estimates indicate that forage production has been reduced below $50 \%$ of potential on $70 \%$ of Oklahoma's rangeland. Also, forage production on over 4 million of Oklahoma's 6.3 million hectares $(65 \%)$ of rangeland could be increased by some form of brush control (Soil Conservation Service 1982).

Much of the decline in the condition of Oklahoma's rangeland may be attributed to the reduced profitability of cattle enterprises and its depressing effect on incentives to invest in range improvements. Implementation of most brush control practices requires substantial initial investment followed by increased annual benefits experienced several years into the future. Many producers'

\footnotetext{
Authors are assistant professor, Agricultural Economics Department; professor Agronomy Department; and assistant professor, Animal Science Department, Oklahoma State University, Stillwater 74078 . This article has been approved hy the Oklahoma Agriculture Experiment Station as Journal Article $\mathbf{5 2 5 2 .}$

Manuscript accepted 29 October 1987.
}

financial position precludes them from incurring the negative influence of these investments on initial annual cash flows. Range improvement practices are needed that require low initial investment and provide immediate benefit in the form of improved animal performance or production.

Prescribed burning has been advocated as a profitable range improvement practice under the economic environment currently faced by livestock producers. The most appealing feature of latespring burning is that it provides immediate benefits in the form of increased stocker cattle weight gains (Anderson et al. 1970, Owensby and Smith 1979). These short-term benefits result from improvements in the quality of forage available to grazing cattle (Allen et al. 1976). Data from Kansas (Anderson et al. 1970, Owensby and Smith 1979, and Woolfolk et al. 1975) and Oklahoma (McCollum 1987) indicate that summer gains of yearling cattle on tallgrass prairie increase 10 to $20 \%$ in response to prescribed burning. Burning also provides long-term range improvement by advancing grassland succession and favoring desirable grasses (Anderson et. al. 1970, McMurphy and Anderson 1965, and Towne and Owensby 1984) and controlling undesirable weed and brush species, especially eastern redcedar (Anderson et al. 1970, Stritzke et al. 1975, and Stritzke and Rollins 1984). Thus, prescribed burning offers the producer an opportunity to meet the long-term goals of income stability, increased net worth, and improved range condition without incurring significant negative cash flows in the initial portion of the planning horizon. Of course, prescribed burning is not without its disadvantages. Reductions in soil moisture as a result of burning can decrease forage yield in dry years (Anderson et al. 1970). In addition, improper timing of prescribed burns and poor grazing practices on burned rangeland can have considerable detrimental effects (Towne and Owensby 1984, Anderson et al. 1970).

Economic analysis of range improvement investments has traditionally been conducted through application of net present value (NPV) criteria in a partial budgeting framework. Annual cash flows (income less costs) are estimated over the investment's life, discounted by an appropriate discount rate, then summed to determine the NPV of the investment. The NPV estimates may then be used to estimate the profitability of an investment or rank alternative investments. Previous applications of this approach 
include Whitson and Scifres 1981, McBryde et al. 1984, Garoian et al. 1984, and Scifres 1985. Cotner (1963) and Jameson (1971) employed a variation of this discounting approach to determine optimum timing of range improvement controls.

The primary shortcoming of these analyses is that they are deterministic, ignoring the uncertainty inherent in livestock production and the effect of this uncertainty on the economic feasibility on the range investment. Production response is based upon expected forage and animal response to the range improvement practice. Also, product prices and factor costs are set at predetermined levels. When evaluating range investments, consideration must be given to the effect of adoption on risk (income variability) as well as expected income levels. Range improvement practices that increase risk along with expected income may not necessarily be production techniques preferred by the rancher. Thus, criteria based upon income variability as well as profitability measures should be employed to evaluate the efficacy of range investments (Cook and Stubbendieck 1986).

A second shortcoming of range investment analyses conducted using a partial budgeting framework is their failure to fully represent the economic consequences associated with a range improvement program. The influence of a negative annual cash flow not only affects the NPV of income in the current year, but also reduces income in future years if additional debt is incurred to cover operating losses. A whole-ranch approach must be employed to accurately measure the economic ramifications of a particular range improvement investment.

The objective of this study is to evaluate the influence of prescribed burning on both the expected value and variability of net returns from a representative stocker enterprise. Economic evaluations of a burning program on shallow prairie and eroded prairie range sites are reported.

\section{Methods and Procedures}

\section{Model Description}

To represent the effect of prescribed burning in an uncertain production and economic environment, a stochastic (Monte Carlo) simulation model was employed. Monte Carlo models have been advocated as a useful means of exploring alternative investment strategies and their uncertain consequences (Anderson et al. 1980). Monte Carlo simulation involves the mathematical representation of a system, wherein critical stochastic variables are represented using specified probability distributions. In economic applications, important product prices, costs, and yield are typically specified as stochastic variables. Random variables drawn from these distributions are used in the model to simulate the firm's performance. By repeating this procedure many times, probability distributions of important economic performance measures can be derived.

The simulation model used in this study was developed to represent the production, marketing, and financial aspects of a representative ranch over a 1-year planning horizon. The model includes several stochastic factor cost, output price, and livestock response variable to represent the uncertainty inherent in stocker cattle enterprises. Through repeated iterations of the simulation model, the effect of various range improvement practices (e.g., prescribed burning) on both the expected value and variability of ranch income may be obtained.

To simulate the representative ranch operation, the model is initialized using a predetermined ranch situation, then run for a 10-year planning horizon following a specified management plan. The initial ranch situation dictates the beginning financial position, range condition, and resource endowments of the representative ranch. At the beginning of each year, steer prices, calf prices, feed prices, and livestock production performance variables are drawn from a multivariate probability distribution. These values are then entered into the model to estimate annual ranch income derived from the specified seasonal management plan. The user- specified management plan stipulates the complete set of production and marketing decisions made by the producer (the number of calves purchased, feed rations, range improvement practices, marketing dates, etc.). The ranch operation is simulated recursively, using the ending financial and resource situation for 1 year as the beginning position for the next.

Alternative range improvement practices may be evaluated using the ranch simulation model by programming the particular practice into the specified production plan. For example, in evaluating the adoption of a prescribed burning program, probability distributions and relationships defining animal performance and range productivity in response to late-spring burning are specified. Also, additional costs of burning are included in the simulation model. The model is run for several iterations to derive distributions of relevant economic variables to be used in evaluating the range improvement investment. The economic consequences associated with prescribed burning may then be determined by comparing these results with those derived under baseline conditions (without prescribed burning). The model may also be under deterministic (no-risk) conditions by fixing each stochastic variable at its expected value. Comparison of the results derived using the stochastic and deterministic specifications indicate the effect of incorporating risk in the range investment analysis.

\section{Production Response}

Production data included in this analysis were restricted to those specific yield changes that affect the quantity of marketable product (beef). These include long-run changes in stocking rate associated with adopting (or failing to adopt) a burning program, as well as changes in forage quality that alter the expected value and variability of annual weight gains.

Herbage availability was estimated from Soil Conservation Service Technical Guide ${ }^{1}$ herbage yield data for tallgrass rangeland of the Central Rolling Red Prairies Land Resource Area, Payne County, Oklahoma. These data were supported by forage standing crop data for the same area (Powell et al. 1982, Rollins et al. 1985, Brummer 1986, and Engle et al. 1987). In the absence of eastern redcedar trees, peak standing crop (i.e., late July to early August standing crop) was set at $3,360 \mathrm{~kg} / \mathrm{ha}(3,000 \mathrm{lb} / \mathrm{ac})$ on shallow prairie and $2,800 \mathrm{~kg} / \mathrm{ha}(2,500 \mathrm{lb} / \mathrm{ac})$ on eroded prairie, the approximate long-term averages as suggested by these clipping data. Initial herbage availability of 2,800 and $2,240 \mathrm{~kg} / \mathrm{ha}(2,500$ and $(2,000 \mathrm{lb} / \mathrm{ac})$ for shallow prairie and eroded prairie, respectively, reflects reduced herbage standing crop associated with infestations of 198, 2 to $6 \mathrm{~m}$ (6 to $20 \mathrm{ft}$ ), eastern redcedar trees per hectare, which was adapted from the standing crop data provided by Engle et al. (1987).

Forage release, a result of eastern redcedar control with annual spring burning, is estimated to be maximized in 3 years. The greatest proportion of herbage availability increase is assumed to occur with the first annual burn. With no spring burning, herbage availability would linearly decline to about 1,792 and $1,680 \mathrm{~kg} / \mathrm{ha}$ $(1,600$ and $1,500 \mathrm{lb} / \mathrm{ac})$ on shallow prairie and eroded prairie sites, respectively, as a result of additional eastern redcedar encroachment. Thus, over the 10 -year planning horizon, eastern redcedar population is assumed to increase from about 198 trees/hectare $(80$ trees/ac) to 568 trees/hectare ( 230 trees/ac) on the shallow prairie and from 198 to 420 trees/hectare $(80$ to 170 trees/ac) on the eroded prairie range sites. ${ }^{2}$ Estimated herbage availability over the 10-year time horizon is depicted graphically for both shallow and eroded prairies in Figures 1a. and 2a., respectively.

Stocking rate was set by allowing 12.0 kilograms ( 26.5 pounds) herbage/steer/day for herbage disappearance, the herbage disappearance associated with stocker cattle grazing tallgrass prairie

U.S.D.A. Soil Conservation Service, Field Office, Stillwater, Oklahoma. ${ }^{2}$ Based upon an average herbage reduction of $13.23 \mathrm{~kg}(6.0 \mathrm{lbs}$.) per tree (Engle et al. 1987). 

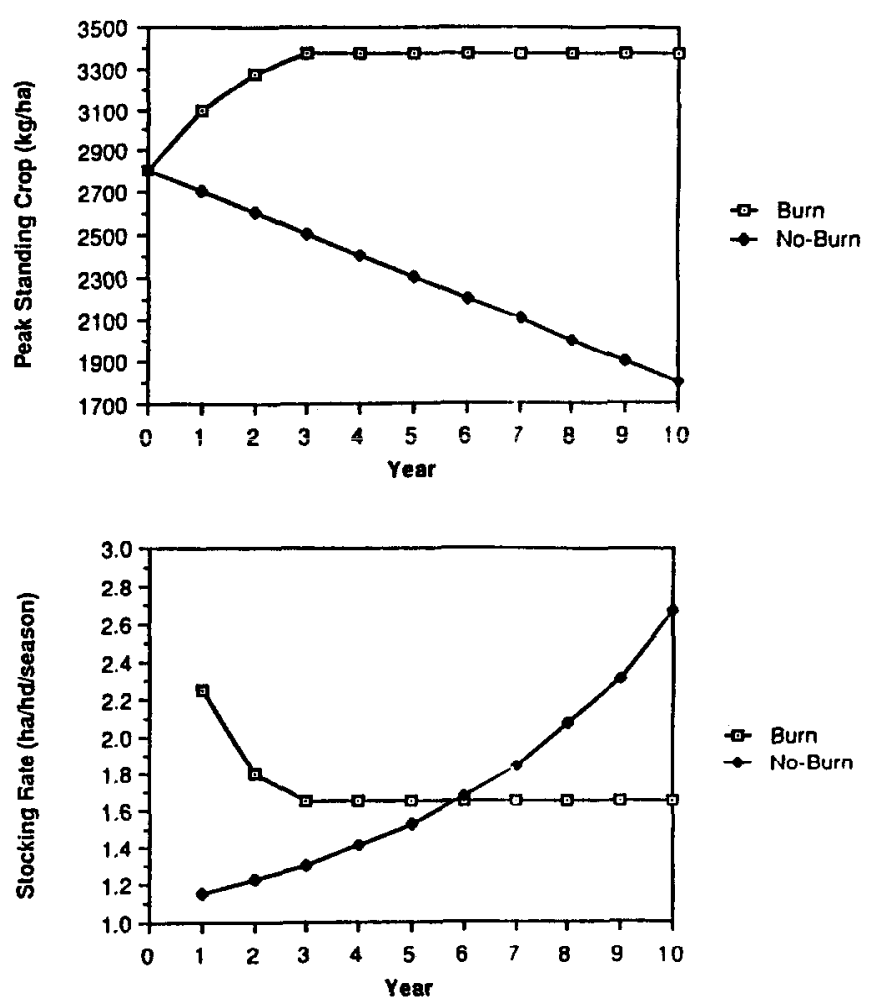

Fig. 1. Peak standing crop and associated stocking rates for the 10-year time horizon, shallow prairie range site.
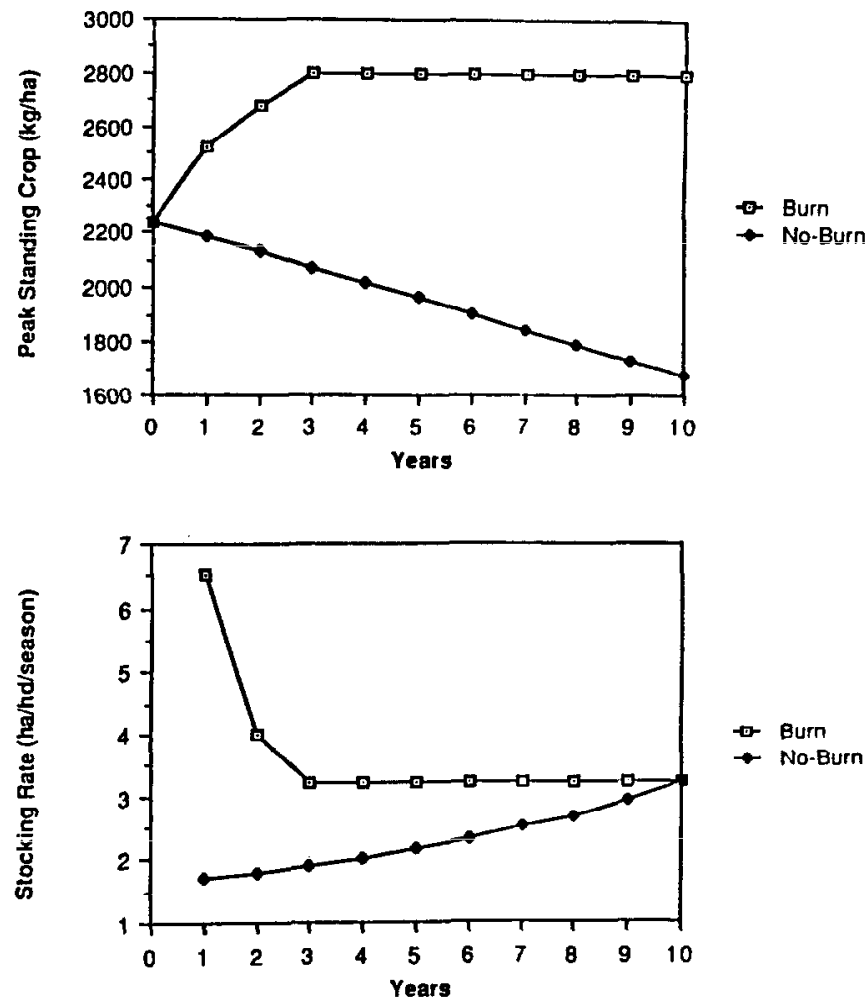

Fig. 2. Peak standing crop and associated stocking rates for the 10-year time horizon, eroded prairie range site.

(Brummer 1986). Stockers are grazed from late-April to lateSeptember, a period of approximately 150 days. Herbage allocation on burned pastures was limited to herbage in excess of 2,240 $\mathrm{kg} / \mathrm{ha}(2,000 \mathrm{lb} / \mathrm{ac})$ residue, the fine fuel threshold requirement for late spring burning for eastern redcedar control (Launchbaugh and Owensby 1978, Rollins 1985). On unburned pastures, herbage in excess of $1,120 \mathrm{~kg} / \mathrm{ha}(1,000 \mathrm{lb} / \mathrm{ac})$ was allocated for stocker use. Stocking rates approximate those calculated by Kothmann's (1984) method and the SCS Technical Guide recommended stocking rates, except that stocking rate was set lower on burned pasture to conserve fuel for burning. Our calculated stocking rates on unburned pastures were heavier than Kothmann's in the first portion of the 10-year period to approximate conventional stocking in the region. The derived stocking rates under burn and no-burn conditions for summer stocker production on shallow prairie and eroded prairie range sites are shown in Figures $\mathbf{l b}$. and $\mathbf{2 b}$.

To represent the short-term effect of prescribed burning, triangular probability distributions of annual steer performance (seasonal weight gain) were derived using late-spring burning from the Kansas Flint Hills and data from Oklahoma State Univeristy (Launchbaugh and Owensby 1978, Owensby and Smith 1979, and McCollum 1987). These distributions reflect the expected value and variability of steer performance resulting from differences in forage quality among years. Prescribed burning is estimated to improve summer gains of yearling cattle an average of $12 \%$ on tallgrass prairie in Oklahoma (McCollum). Results reported from several studies investigating the effects of late-spring burning suggest similar improvement in gain from burning (Anderson et al. 1970, Smith and Owensby 1972, Woolfolk et al. 1975, and Owensby and Smith 1979). Mean annual weight gains of 113.4 and 102.1 kilograms ( 250 and 225 pounds) per steer were specified in the burn and no-burn distributions, respectively. To obtain an estimate of the degree of variability in annual steer gains, a 10-year data set was employed. Since statistical tests indicate no serial correlation, the data were used to estimate the distribution of annual steer weight gains with and without prescribed burning. For reasons cited in Young (1983), 10 and 90 percentiles were substituted for exact endpoints in deriving distribution parameters from the data series. The derived triangular distributions are shown in Figure 3.

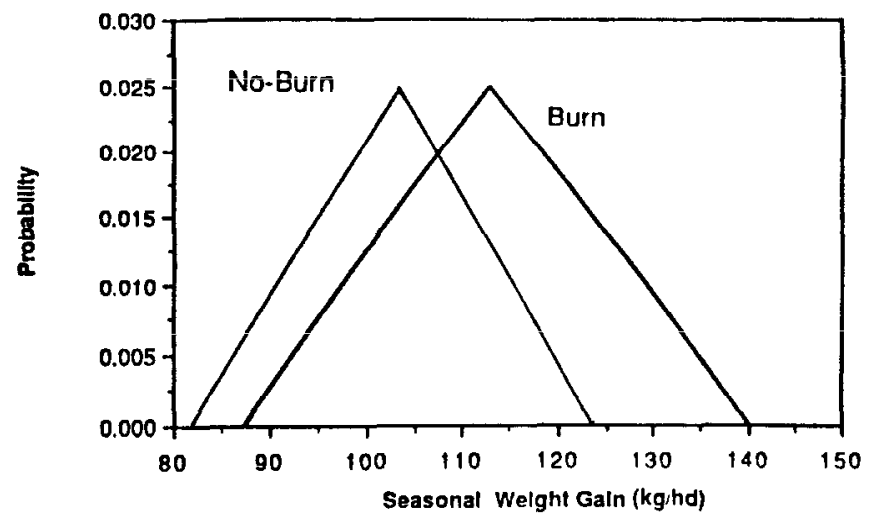

Fit. 3. Triangular probability distributions of seasonal weight gain on a $216 \mathrm{~kg}(475 \mathrm{lb})$ steer, with and without prescribed burning.

\section{Livestock Receipts and Production Costs}

Net returns were determined by combining values derived from the production response models with stochastically derived product price and factor cost estimates. Steer prices, supplemental feed costs (prairie hay and protein supplement), and calf prices were represented using a multivariate normal distribution based upon a historical series of normalized price data. Mean values of distribution variables were determined exogenously from price models that reflect the level of expected values of each price over the time horizon.

Gross livestock receipts were estimated as the product of 3 variables: (1) the number of steers grazed (as dictated by the current 
stocking rate), (2) the average steer weight (derived from the production model), and (3) the stochastic steer price. Revenues were adjusted to reflect a $2 \%$ death loss. Average steer and calf prices were determined from price prediction models specified to represent seasonal and cyclical movements of cattle prices over time.

Annual costs allocated to the stocker enterprise included livestock and non-livestock costs associated with ownership and maintenance of the representative ranch. An itemized list of annual livestock expenses (with stochasic prices set at expected values) is presented in Table 1. Estimated annual costs of pasture burning

Table 1. Per head operating cost for stocker steers on eroded prairic and shallow prairle range sites.

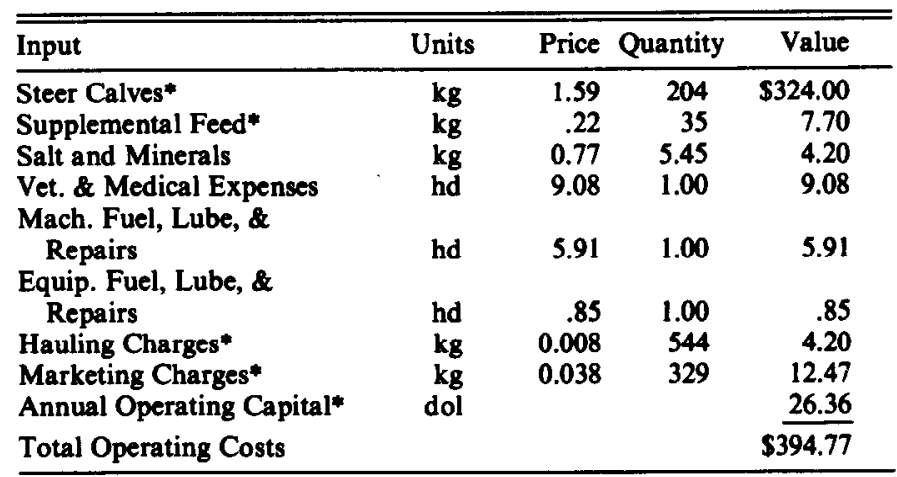

* The actual cost of this input is dependent upon stochastic prices or stochastic weight gain values. Costs reported are expected values.

were estimated to be $\$ 5.73$ per hectare (\$2.32 per acre). Non-livestock expenses included interest and principal payments on short-, and intermediate-term debt, land rental and ownership expenses, property taxes, pasture maintenance and improvement costs, and various ranch overhead expense items. Additional debt may be accumulated over the planning horizon through financing of operating losses.

\section{Results and Discussion}

The simulation model was applied to investigate the profitability of implementing a prescribed burning program on both shallow prairie and eroded prairie range sites to control eastern redcedar. The profitability of the burning program was estimated by comparing simulation results derived from an enterprise employing latespring burning each year with baseline results (without prescribed burning).

The current stocker enterprise was assumed to consist of 300 head of stocker steers grazed on 607 hectares (1,500 acres) of tallgrass prairie range. Stocker calves weighing 215.5 kilograms (475 pounds) are purchased in early-April, placed in a 28 -day receiving program, and then grazed until late-September (approximately 150 days). Steers are supplemented with 0.45 kilograms (1 pound) of soybean meal per day over the last 77 days of the summer grazing season.

\section{Shallow Prairie Range Site}

Expected annual cash flows (receipts less operating costs) from stocker production on a shallow prairie range site were estimated for both burn and no-burn scenarios under stochastic (risk) and deterministic (no-risk) conditions. Annual cash flows from each year of the 10-year planning horizon, accumulated cash flow and the net present value of the cash flows are given for each scenario in Table 2. A real discount rate of $4 \%$ was used to estimate the net present value of the 10-year return stream. ${ }^{3}$ The risk results represent the expected values of the annual cash flows from 200 itertions of the simulation model. In the deterministic analysis, expected

\footnotetext{
${ }^{3}$ All prices and costs employed in the model are expressed in real (non-inflated) terms. Thus, a real discount rate (4\%) is employed to represent the opportunity cost associated with investing money in the enterprise (Workman 1986).
}

cash flows were estimated using expected values of annual steer performance (weight gain), input cost, and steer price variables.

Results indicated that prescribed burning is an economically feasible range improvement practice for stocker producers operating on shallow prairie range sites. Under stochastic conditions, the net present value (NPV) of the return stream generated using prescribed burning exceeds the no-burn NPV by $\$ 41,905$ or $\$ 69.04$ per hectare (\$27.94 per acre). Expected returns derived when burning is used exceed no-burn returns for all but the first year of the planning horizon, despite the higher no-burn stocking rate for years 1 through 5 (see Fig. 1b). In years 2 through 5, additional returns derived from improved animal performance on burned pastures exceed returns lost from the lower stocking rate. Returns from prescribed burning increased over the first 3 years of the planning horizon and then appeared to level off. Conversely, returns from no burn scenarios decrease monotonically over time as a result of the declining stocking rate.

Comparison of results derived under risk and no-risk assumptions indicates a decrease in the estimated profitability of stocker production as a result of incorporating stochastic economic and production influences. The NPV of returns derived from deterministic application of the model exceed stochastic estimates for the burn and no-burn scenarios (Table 2). Also, mean annual cash flows from the deterministic analysis exceed annual cash flows for each year of the stochastic analysis. This result primarily reflects 2 conditions. First, because output and factor price variables are not independent, the expected value of net returns under stochastic conditions is not necessarily equivalent to the net return generated using expected price and production values. Also, under stochastic conditions, negative annual cash flows may result from poor animal performance, low steer prices, and/or high factor costs. Financing these operating losses results in an increase in annual operating expenditures relative to those estimated under deterministic assumptions.

Results from the stochastic analysis also indicate the influence of annual prescribed burning on the variability of annual cash flows. Table 2 reports the mean, standard deviation, and coefficient of variation of annual returns for the burn and no-burn scenarios. The standard deviation of annual cash flows increases for 6 of the 10 years of the planning horizon as a result of adopting a prescribed burning program. However, when variability in returns is measured using the coefficient of variation, the variability of returns derived from the no-burn scenario exceeds the variability resulting from using the burning program in 9 of the 10 years. Furthermore, the magnitude of this difference increases over time.

It may be argued that return variability does not accurately reflect the risk inherent in a particular livestock enterprise since both deviations above and below the mean contribute to the estimated level of risk. Several researchers have proposed a "safetyfirst" risk measure where the degree of risk inherent in an enterprise is measured by the probability of returns falling below some critical level (Walker et al. 1986, Robinson et al. 1984). To illustrate this concept, the probability of annual cash flows falling below zero during each year of the time horizon is given in Figure 4. When a critical return level of zero is assumed, the level of risk in stocker production is reduced in every year as a result of implementing a burning program. The probability of negative annual cash flows is reduced from 5\% in year 1 to as much as $26 \%$ in year 10 .

\section{Eroded Prairie Range Site}

Expected annual cash flows for stocker enterprises on eroded prairie range sites are given in Table 3. Under both stochastic and determinist assumptions, the NPV of returns from the burning scenario exceed those derived from the no-burn scenario. This result occurs despite the fact that annual cash flows from stocker production without prescribed burning exceed cash flows from the prescribed burning scenario for the first 3 years of the planning horizon. Higher productivity of burned range sites (and lower productivity of unburned sites) results in increased stocking rates 
Table 2. Annual cash now parameters for a stocker cattle enterprise on a shallow prairie range site.

\begin{tabular}{|c|c|c|c|c|c|c|c|c|}
\hline \multirow[b]{3}{*}{ Year } & \multicolumn{4}{|c|}{ With prescribed burning } & \multicolumn{4}{|c|}{ Without prescribed burning } \\
\hline & \multicolumn{3}{|c|}{ Risk } & \multirow{2}{*}{$\frac{\text { No-Risk }}{\text { Mean }}$} & \multicolumn{3}{|c|}{ Risk } & \multirow{2}{*}{$\frac{\text { No-Risk }}{\text { Mean }}$} \\
\hline & Mean & S.D. & c.V. & & Mean & S.D. & c.V. & \\
\hline $\begin{array}{r}1 \\
2 \\
3 \\
4 \\
5 \\
6 \\
7 \\
8 \\
9 \\
10\end{array}$ & $\begin{array}{r}4224 \\
6565 \\
7914 \\
8543 \\
8609 \\
9362 \\
9568 \\
9578 \\
10958 \\
12036\end{array}$ & $\begin{array}{l}10018 \\
11816 \\
13670 \\
13440 \\
13741 \\
13589 \\
13832 \\
13964 \\
13121 \\
13822\end{array}$ & $\begin{array}{l}2.37 \\
1.80 \\
1.72 \\
1.57 \\
1.60 \\
1.45 \\
1.44 \\
1.46 \\
1.20 \\
1.15\end{array}$ & $\begin{array}{r}4426 \\
6879 \\
8627 \\
8923 \\
9190 \\
9371 \\
9583 \\
9830 \\
11118 \\
12450\end{array}$ & $\begin{array}{l}5970 \\
5639 \\
4838 \\
3673 \\
4454 \\
3708 \\
3090 \\
1662 \\
1014 \\
-134\end{array}$ & $\begin{array}{c}17313 \\
16662 \\
16594 \\
13828 \\
13732 \\
12215 \\
1955 \\
11284 \\
9263 \\
4175\end{array}$ & $\begin{array}{r}2.90 \\
2.95 \\
3.43 \\
3.76 \\
3.08 \\
3.29 \\
3.54 \\
6.78 \\
9.13 \\
31.15\end{array}$ & $\begin{array}{l}7369 \\
6634 \\
5974 \\
5372 \\
4787 \\
4111 \\
3513 \\
2924 \\
2448 \\
1890\end{array}$ \\
\hline $\begin{array}{l}\text { ACF } 1 \\
\text { NPV }^{2}\end{array}$ & $\begin{array}{l}87,357 \\
71,075\end{array}$ & & & $\begin{array}{l}90,397 \\
71,559\end{array}$ & $\begin{array}{l}33,914 \\
29,170\end{array}$ & & & $\begin{array}{l}45,022 \\
38,108\end{array}$ \\
\hline
\end{tabular}

'Accumulated cash flow

2Net present value (4\% discount rate)

Table 3. Annual cash flow parameters for a stocker cattle enterprise on an eroded prairie range site.

\begin{tabular}{|c|c|c|c|c|c|c|c|c|}
\hline \multirow[b]{3}{*}{ Year } & \multicolumn{4}{|c|}{ With prescribed burning } & \multicolumn{4}{|c|}{ Without prescribed burning } \\
\hline & \multicolumn{3}{|c|}{ Risk } & \multirow{2}{*}{$\frac{\text { No-Risk }}{\text { Mean }}$} & \multicolumn{3}{|c|}{ Risk } & \multirow{2}{*}{$\begin{array}{c}\text { No-Ris } \\
\text { Mean } \\
\end{array}$} \\
\hline & Mean & S.D. & c.v. & & Mean & S.D. & C.V. & \\
\hline $\begin{array}{r}1 \\
2 \\
3 \\
4 \\
5 \\
6 \\
7 \\
8 \\
9 \\
10\end{array}$ & $\begin{array}{r}-2784 \\
-665 \\
985 \\
1100 \\
1172 \\
666 \\
711 \\
1392 \\
481 \\
685\end{array}$ & $\begin{array}{l}3414 \\
4875 \\
6948 \\
6995 \\
6837 \\
7369 \\
6831 \\
6339 \\
7514 \\
7128\end{array}$ & $\begin{array}{r}1.23 \\
7.33 \\
7.05 \\
6.35 \\
5.83 \\
11.06 \\
9.61 \\
4.55 \\
15.62 \\
10.40\end{array}$ & $\begin{array}{r}-2769 \\
-464 \\
1340 \\
1691 \\
2016 \\
2256 \\
2529 \\
2840 \\
3193 \\
3592\end{array}$ & $\begin{array}{r}2273 \\
1835 \\
704 \\
825 \\
899 \\
-210 \\
-196 \\
-1840 \\
-3168 \\
-3873\end{array}$ & $\begin{array}{r}12320 \\
10684 \\
9657 \\
9700 \\
9846 \\
9648 \\
8469 \\
9428 \\
8226 \\
8221\end{array}$ & $\begin{array}{r}5.42 \\
5.82 \\
13.72 \\
11.76 \\
10.95 \\
45.94 \\
43.21 \\
5.12 \\
2.60 \\
2.12\end{array}$ & $\begin{array}{c}2754 \\
2489 \\
1664 \\
1515 \\
1324 \\
1100 \\
1003 \\
-391 \\
-1836 \\
-2801\end{array}$ \\
\hline $\begin{array}{l}\text { ACF1 } \\
\text { NPV } 2\end{array}$ & $\begin{array}{l}3,743 \\
2,372\end{array}$ & & & $\begin{array}{l}16,224 \\
11,652\end{array}$ & $\begin{array}{r}-2,751 \\
-549\end{array}$ & & & $\begin{array}{l}6,821 \\
6,975\end{array}$ \\
\hline
\end{tabular}

Accumulated cash flow

${ }_{2}$ Net present value (4\% discount rate)

and higher annual returns on burned ranges in the final 7 years of the planning horizon. Accumulated cash flows under prescribed burning greatly exceed no-burn cash flows in both the stochastic and deterministic analyses. However, because the primary income generating potential of burned range sites occurs in later years, a majority of these cash flows are heavily discounted. Therefore, the profitability of prescribed burning, as measured by the difference in burn and no-burn returns, is reduced. The difference between the NPVs derived with and without prescribed burning is $\$ 2,921$ and and \$4,677 under risk and no-risk conditions, respectively.

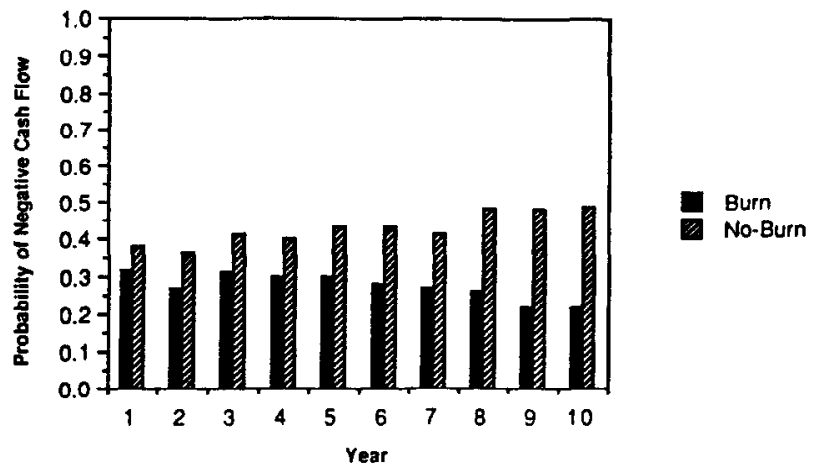

Fig. 4. Probability of negative annual cash-flows over the 10-year time horizon, shallow prairie range site.
Despite the short- and long-term benefits of prescribed burning, the accumulated cash flow from stocker production on eroded prairie is quite low under the economic assumptions of the analysis. Under stochastic conditions, the stocker enterprise nets less than $\$ 375$ per annum when used in conjunction with prescribed burning and \$275 per year without a burning program. Similarly, average annual cash flows from the deterministic analysis range from only $\$ 682$ to $\$ 1,622$.

As on shallow prairie range sites, the adoption of prescribed burning decreases the risk inherent in the summer stocker enterprise. When measured by the variance and coefficient of variation of annual cash flows, the variability of annual returns is greater under no-burn conditions. Also, the probability of negative annual cash flows from the no-burn scenario exceeds that derived from the prescribed burning scenario in all but the first 2 years of the 10 -year planning horizon (Fig. 5).

\section{Summary and Conclusions}

Stochastic simulation and deterministic results indicate that prescribed burning is an economically feasible range improvement practice for eastern redcedar control on both shallow prairie and eroded prairie range sites. Under deterministic conditions, the NPV of returns from the burning scenario exceed those from the no-burn scenario by $\$ 33,451$ on shallow prairie range sites and $\$ 4,667$ on eroded prairie range sites. When the effects of stochastic production response, factor costs, and product prices are incorpo- 


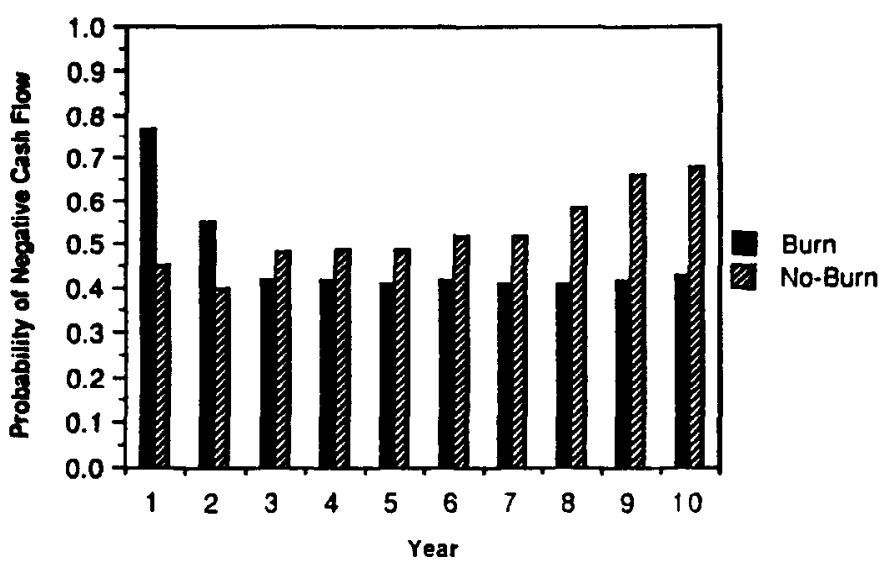

Fig. 5. Probability of negative annual cash-flows over the 10-year time horizon, eroded prairie range site.

rated, the profitability of prescribed burning is reduced below estimates derived under deterministic conditions. Nonetheless, NPV estimates derived from the burning scenario still exceed those estimated without burning on both range sites.

A prescribed burning program does increase the variability of annual income derived from stocker production. However, much of this increase in dispersion may be attributed to an increase in the probability and magnitude of deviations above the mean value. When risk is measured in terms of relative dispersion (coefficient of variation) and the probability of negative annual cash flows, prescribed burning is shown to reduce the risk associated with stocker production.

The results presented here should be interpreted in light of the assumptions used in the analysis. A number of factors may influence the relative profitability of range improvement investments, including weather, treatment cost, range site potential, initial range condition, and projected product and input costs. In addition, the derived results are specific to the financial, production, and resource conditions that characterize the representative ranch. Application of the model to alternative economic and environmental conditions, as well as other range improvement practices, requires respecification of the production and economic data used in the analysis.

\section{Literature Cited}

Allen, L.J., E.F. Smith, R.R. Schalles, B.E. Brent, L.H. Harbers, and C.E. Owensby. 1976. Effects of range burning and nitrogen fertilization on the nutritive value of bluestem. J. Range Manage. 29:306-308.

Anderson, K.L., E.F. Smith, and C.E. Owensby. 1970. Burning bluestem range. J. Range Manage. 23:81-92.

Anderson, J.R., J.L. Dillon, and J.B. Hardaker. 1980. Agricultural decision aalysis. Iowa State Univ. Press, Ames.

Brummer, J.E. 1986. Vegetation dynamics of the tallgrass prairie under short duration grazing. M.S. Thesis, Oklahoma State Univ., Stillwater. Cook, C.W., and J. Stubbendieck (Eds.) 1986. Range research: basic problems and techniques. Soc. Range Manage., Denver, Colo.

Cotner, M.C. 1963. Optimum timing of long-term resource improvements. J. Farm Econ. 45:732-748.
Engle, D.M., J.F. Stritzke, and P.L. Claypool. 1987. Herbage standing crop around eastern redcedar trees. J. Range Manage. 40:237-239.

Garoian, L., J.R. Conner, and C.J. Sctires. 1984. Economic evaluation of fire-based improvement systems for Macartney rose. J. Range Manage. 37:111-115.

Jameson, D.A. 1971. Optimum stand selection for juniper control on southwestern woodland. J. Range Manage. 24:94-99.

Launchbaugh, J.L., and C.E. Owemby. 1978. Kansas rangelands: their management based on a half century research. Kansas Agr. Exp. Sta. Bull. 622 .

Kothmann, M.M. 1984. Concepts and principles underlying grazing systems. p. 903-916. In: NRC/NAS, Developing Strategies for Rangeland Management. Westview Press. Boulder, Colo.

McBryde, G.L., J.R. Conner, and C.J. Seifres. 1984. Selected brush management practices for eastern south Texas. Texas Agr. Exp. Sta. Bull.

McCollum, F.T. 1987. Integrating livestock decisions with brush management in the Cross Timbers. p. 32-41. In: D. Rollins (ed.), Proc. of Brush Management in the Cross Timbers. OkJahoma Coop. Ext. Serv. Circ. E-862.

McMurphy, W.E., and K.L. Anderson. 1965. Burning Flint Hills range. J. Range Manage. 18:265-269.

Owensby, C.E., and E.F. Smith. 1979. Fertilizing and burning Flint Hills bluestem. J. Range Manage. 32:254-258.

Powell, J., J.F. Stritzke, R.W. Hammond, and R.C. Morrison. 1982. Weather, soil and 2,4-D effects on tallgrass prairie in Oklahoma. J. Range Manage. 35:483-488.

Robinaon, L.J., P.J. Barry, J.B. Kllebenatein, and G.F. Patrick. 1984. Risk attitudes: concepts and measurement approaches. In: P.J. Barry (ed.), Risk Management in Agriculture. Iowa State University Press. Ames.

Rollins, D. 1985. Controlling eastern redcedar with prescribed fire. p. 71-83. In: R. Wittwer and D. Engle (eds.), Proc. Eastern Redcedar in Oklahoma Conf. Oklahoma Coop. Ext. Serv. Circ. E-849.

Rollins, D., J.F. Stritzke, R.L. Gilen, C.K. Rice. 1985. Range improvement studies-1984. Oklahoma Agr. Exp. Sta. Cur. Rep. CR-2859.

Sclifes, C.J. 1985. Integrated brush management systems for south Texas: development and implementation. Texas Agr. Exp. Sta. Bull. B-1493.

Smith, E.F., and C.E. Owensby. 1972. Effect of fire on true prairie grasslands. Tall Timbers Fire Ecology Conf. 12:9-22.

Soil Conservation Service. 1978. Oklahoma resource inventory. Statistical data tables. NRI-1982. USDA, Stillwater, Okla.

Stritzke, J.W., W.E. McMurphy, and R.W. Hammond. 1975. Brush control with herbicides: Sarkey's research and development report. Oklahoma Agr. Exp. Sta. Misc. Pub. MP-95.

Stritzke, J.F., and D. Rollins. 1984. Eastern redcedar and its control. Oklahoma Coop. Ext. Serv. Ext. Fact No. 2850.

Towne, G., and C.E. Owenaby. 1984. Long-term effects of annual burning at different dates in ungrazed Kansas tallgrass prairie. J. Range Manage. 37:392-397.

Walker, O.L., D.J. Bernardo, and P.H. Gutierrez. 1986. A Monte Carlo approach to generating distributions of cattle returns. Proc. of Southern Regional Research Committee S-180, Tampa, Florida.

Whitson, R.E., and C.J. Scifres. 1981. Economic comparison of honey mesquite control methods with special reference to the Texas Rolling Plains. J. Range Manage. 34:415-420.

Woolfolk, J.S., E.F. Smith, R.R. Schalles, B.E. Brent, L.H. Harbers, and C.E. Owensby. 1975. Effects of nitrogen fertilization and late-spring burning of bluestem range on diet and performance of steers. J. Range Manage. 28:190-193.

Workman, J.P. 1986. Range economics. MacMillan and Company, New York, New York.

Young, D.L. 1983. A practical approach for eliciting subjective probability distributions. Paper presented at Amer. Agr. Econ. Assoc. Annu. Meetings, West Lafayette, Ind. 